\title{
Indhold 2013
}

\section{Artikler}

Allern, Sigurd: Kriminaliteten og medierne

Bragadóttir, Ragnheidur: Hvordan straffes for voldtægt? ............................. 285

Bragadóttir, Ragnheidur: Straf for miljøforbrydelser i Island ...................... 257

Christie, Nils: Restoration after atrocities .................................................. 324

Garde, Peter: Nordisk Tidsskrift for Kriminalvidenskab 1913-2013 ........... 2

Gröning, Linda: Straffrättssystemets funktion vid familjevåldbrott mot

barn: problem, utgångspunkter, perspektiv och svar ...

Holgersson, Stefan: Sättet att bygga fasader inom svensk polis. En analys

av presenterad bild jämfört med verkligt utfall

Holmberg, Lars: Politiets brug af peberspray - en skandinavisk sammen-

ligning med fokus på Danmark

Huitfeldt, Iver: Kommentar til innlegget fra professor Träskman ................. 356

Høviskeland, Hans Tore: Strenge straffe for miljøkriminalitet i Norge ......... 228

Kamber, Simon: Psykisk syge lovovertrædere i et komparativt lys .............. 358

Koch, Pernille Boye: Fra Wamberg til PET-tilsyn - en analyse af den nye

danske kontrol med efterretningstjenesterne

Nielsen, Gorm Toftegaard: Hvornår og hvordan straffer vi skattesnydere? .. 302

Nielsen, Gorm Toftegaard: Strafudmåling i miljøstraffesager i Danmark .... 195

Nummela, Heidi: Straff och andra påföljder för miljöbrott i Finland ............. 213

Träskman, Per Ole: Svensk miljöstraffrätt - bister men näbblös hök? .......... 245

Träskman, Per Ole: »The Golden Age of Nordic Cooperation« - Har de nordiska kronjuvelerna kommit på museum? - Den nordiska brottskontrollen: nutid, dåtid och framtid

\section{Boganmeldelser}

Asp, Petter af Anette Storgaard: Sex och Samtycke

Balvig, Flemming, Lars Holmberg og Marie Pi H. Nielsen af Tor-Geir

Myhrer, Gunnar Thomassen og Jon Strype: Verdens bedste politi.

Politireformen i Danmark 2007-2011

Brodeur, Jean-Paul af Paul Larsson: The Policing Web

Greve, Vagn af Christian Häthén: Statens penge. Statens straf 
Greve, Vagn \& Karin Cornils af Jussi Matikkala: Studien zum dänischen Strafrecht - Studies in Danish Criminal Law

Grøvdal, Yngvil af Yngvil Grøvdal: Forældreansvarsloven - når der er vold i familien 276

Hjelm, Ann-Christine af Peter Scharff Smith: Fängslet sin välfärdsbygge ... 388

Lie, Elisabeth Myhre af Marie Torstensson Levander: I forkant. Kriminalitetsforebyggende politiarbeid 386

Sunde, Inger Marie af Heli Lavonen: Automatisert inndragning 167

Ugelvik, Thomas af Matti Tolvanen: Fangenes friheter. Makt och motstand $i$ et norsk fengsel

\section{Debat}

Flyghed, Janne: Den problematiska terroristlagstiftningen

Träskman, Per Ole: Kommentar til Janne Flyghed

\section{Diverse}

Bragadóttir, Ragnheidur: Miljøstrafferet i de nordiske lande 193

Elholm, Thomas: Forord NTfK 100 år

Indhold 2012

Nordisk kriminalistmøte 2013 - Oslo 22.-24. august 285

Träskman, Per Ole: Nekrolog: Inkeri Anttila 1916-2013 384

Årsberetning

Ny litteratur 280 